\title{
Ectopic Thyroid Gland
}

National Cancer Institute

\section{Source}

National Cancer Institute. Ectopic Thyroid Gland. NCI Thesaurus. Code C132051.

Location of the thyroid gland somewhere other than at the base of the neck. 